\title{
Using Microwave Energy for the Removal of Ammonia From Municipal Wastewater: Continuous Flow Lab-Scale System
}

\author{
Fahid K. J. Rabah ${ }^{1} \&$ Mohamad S. Darwish ${ }^{1}$ \\ ${ }^{1}$ Faculty of Civil and Environmental Engineering, The Islamic University-Gaza, Palestine \\ Correspondence: Fahid K. J. Rabah, Faculty of Civil and Environmental Engineering, The Islamic \\ University-Gaza, Palestine. Tel: 97-259-952-8047. E-mail: frabah@iugaza.edu.ps
}

Received: April 10, 2013 Accepted: May 6, 2013 Online Published: May 10, 2013

doi:10.5539/enrr.v3n3p24 URL: http://dx.doi.org/10.5539/enrr.v3n3p24

\begin{abstract}
This work was initiated to investigate the possibility of using a continuous flow Micro Wave (MW) radiation system with heat exchanging for ammonia nitrogen removal from municipal wastewater after the success of using the system as a batch reactor in our previous work. The effects of initial ammonia concentration, detention time, and initial temperature were investigated. The optimum detention time and initial temperature were determined using synthetic wastewater and found to be 8.5 minutes and $62{ }^{\circ} \mathrm{C}$, respectively. These optimum conditions are valid within the range of 60 to $120 \mathrm{mg} \mathrm{NH}_{3} \mathrm{-N} / \mathrm{L}$. The residual concentrations under optimum conditions were $3.5 \pm 0.4,4.4 \pm 0.4,5.1 \pm 0.2$, and $6.9 \pm 0.5 \mathrm{mg} \mathrm{NH}_{3}-\mathrm{N} / \mathrm{L}$ for initial concentrations of $60,70,80$, 100 , and $120 \mathrm{mg} \mathrm{NH}-\mathrm{N} / \mathrm{L}$, respectively. These concentrations meet the $5 \mathrm{mg} \mathrm{NH}-\mathrm{N} / \mathrm{L}$ standard for recharging wastewater to groundwater in many countries such as Jordan .Similar results were obtained using real wastewater samples $\left(3.1 \pm 0.2,4.0 \pm 0.1\right.$ and $4.9 \pm 0.3 \mathrm{mg} \mathrm{NH}_{3}-\mathrm{N} / \mathrm{L}$ for initial concentrations of 65.7, 73.8, and $94.6 \mathrm{mg} \mathrm{NH} \mathrm{N}_{3} \mathrm{~N} / \mathrm{L}$, respectively). The developed system proved to be practical in the continuous flow mode that mimics the actual operations in wastewater treatment plants. It was concluded that MW energy could be one of the most effective methods for large scale removal of ammonia nitrogen from municipal wastewater.
\end{abstract}

Keywords: ammonia, microwave radiation, municipal wastewater, nitrogen

\section{Introduction}

Several methods have been applied to remove ammonia from municipal wastewater such as biological nitrogen removal (BNR), chemical precipitation, ion exchange, ozonation, and air stripping. Biological nitrogen removal is the most commonly used method worldwide. However, this method is sensitive to environmental conditions such as ambient temperature and $\mathrm{pH}$. Moreover, conventional BNR methods require high energy for oxygen supply for the nitrification process (Gujer, 2010) and require high construction cost. Using chemical precipitation for ammonia removal may generate new pollutants in the treated wastewater, because of the required chemical additives (Demirer et al., 2005). For ion exchange technique, the cost of resins' regeneration is high, because nitrate and sulfate anions should be eliminated from the treated wastewater before discharging to the environment (Bochenek et al., 2011). Ozonation method consumes high amounts of energy, which seems economically unfeasible (Yang et al., 1999). Other methods like supercritical water oxidation and air-stripping methods require high operation energy, due to the high temperatures and pressures needed (Bermejo et al., 2008; Değermenci et al., 2012).

In the last few years, microwave (MW) energy became a promising technology. It was studied for several purposes related to environmental applications like treatment of heavy metal contaminated soil (Jou, 2006), remediation of petroleum contaminated soils (Chien, 2012) and hydrocarbon-contaminated soil (Robinson et al., 2012). Focusing on wastewater treatment, MW energy had been applied for several purposes, such as the treatment of ballast water inoculated with invasive organisms (Boldor et al., 2008), remediation of phenol-polluted wastewater (Xiao et al., 2007), treatment of petroleum refinery wastewater (Sun et al., 2008) and safe disposal of highly-contaminated pharmaceutical wastewater (Yang et al., 2009).

After their bench-scale study, Lin et al. (2009) developed a continuous pilot-scale MW system to remove ammonia nitrogen from a real coke-plant wastewater. Under different operating conditions, the ammonia removal could reach about $80 \%$, with initial ammonia concentrations of $2,400-11,000 \mathrm{mg} / \mathrm{L}$. 
Recently, via batch-reactor experiments, the authors of this research studied the characteristics of ammonia removal from municipal wastewater using MW energy and high removal efficiency was achieved. It was found that radiation time and $\mathrm{pH}$ had significant influence on the removal of ammonia nitrogen from municipal wastewater, while the initial ammonia concentration had lower effect (Rabah \& Darwish, 2013).

Following our successful demonstration of ammonia nitrogen removal in batch experiment, a continuous flow bench-scale system was designed and investigated in this research, where treatment of synthetic and real wastewater was carried out. Three factors were investigated: detention time, initial ammonia concentration and initial temperature. A heat exchanger was applied to recover heat energy from the effluent stream in order to utilize it in heating the influent stream and to raise its initial temperature.

The objective of this work was to investigate the possibility of using a continuous flow MW radiation system equipped with heat exchanger after the success of using the system as a batch reactor in our previous work (Rabah \& Darwish, 2013). Moreover, an important objective was to study the performance of this continuous system and to determine the optimum conditions for ammonia nitrogen removal from municipal wastewater.

\section{Materials and Methods}

\subsection{Experimental Setup}

Figure 1 shows a schematic diagram of the experimental apparatus. A domestic microwave oven $(700 \mathrm{~W}, 2450$ MHz, Dura brand XB2316, UK) was used as the source of the MW radiation. Three holes were drilled in the MW body, one on the top cover to insert the ammonia gas evacuation pipe and two at the side to insert the influent and effluent wastewater pipes. A $300 \mathrm{ml}$ glass vessel was placed inside the MW oven and was connected to the three mentioned pipes as shown in the figure. The wastewater was pumped from a $4 \mathrm{~L}$ tank into the glass reactor using a peristaltic pump (SP311, VELP Scientifica). A heat exchanger was used to allow for thermal energy recovery by inserting the influent wastewater pipe in the U-shaped tube that is filled with the continuous hot wastewater flow coming out of the MW. The heat exchanger could be bypassed by installing a bypass pipe controlled by two valves that divert the hot effluent wastewater from the MW directly to the outlet of the system. The ammonia evacuation pipe is connected to a condenser to recover the water vapor and return it back to the effluent stream. Two sampling ports were used to draw samples for the required measurements (one on the influent side, the second at the effluent side as shown in Figure 1).

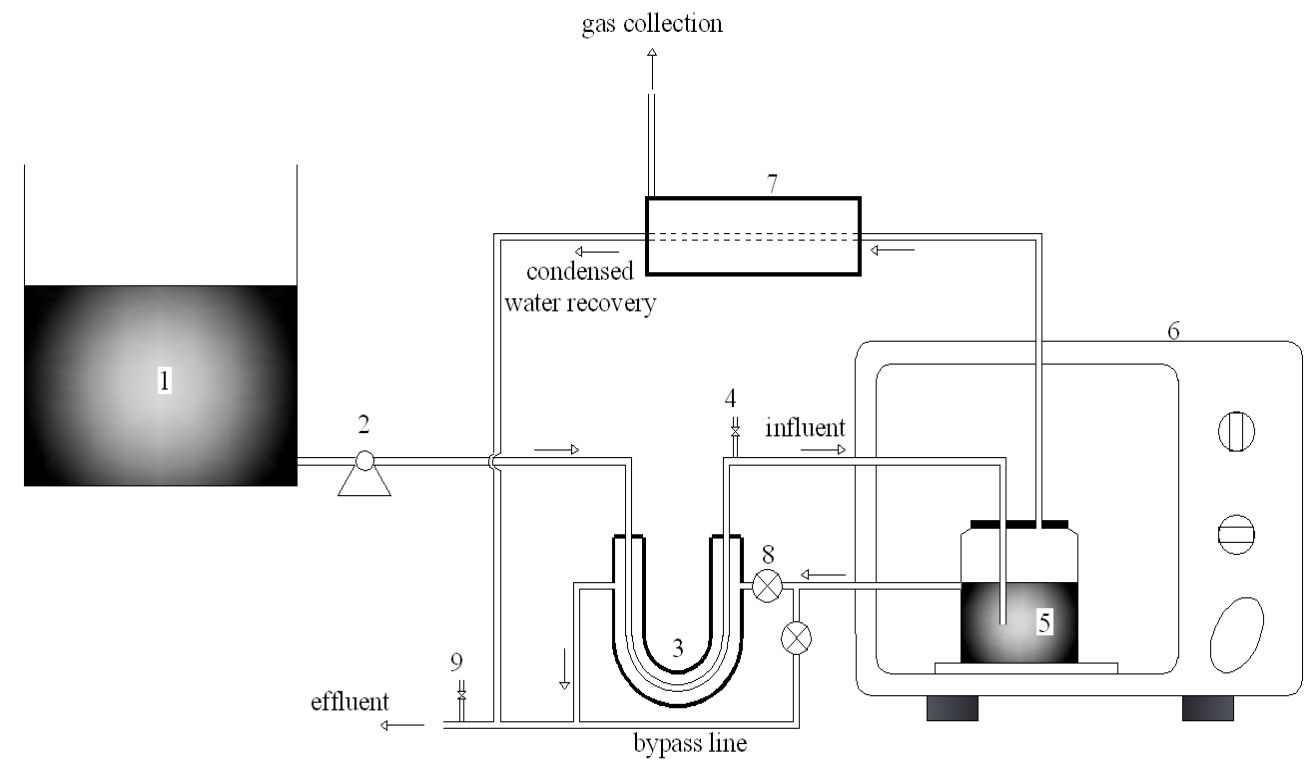

Figure 1. Schematic diagram of the experimental apparatus

(1) Wastewater tank (2) Peristaltic pump (3) Heat exchanger (4) Influent sampling port (5) Glass vessel (6) MW oven (7) Condenser (8) Valve (9) Effluent sampling port. 


\subsection{Materials and Analytical Methods}

Synthetic wastewater (WW) solution was prepared with ammonium chloride (99.5\%, analytical reagent, HiMedia Laboratories, Mumbai, India) and distilled water. The initial $\mathrm{pH}$ of the solution was adjusted at 11 using sodium hydroxide solution ( $\mathrm{NaOH}, 2.0 \mathrm{~mol} / \mathrm{L}, 97.5 \%$, Chemie, Mumbai, India). Real wastewater was taken from the effluent of Gaza wastewater treatment plant.

Temperature of WW was measured by a thermometer and the ammonia nitrogen concentration was measured using Nessler standard method (APHA, AWWA, \& WEF, 1989). In all the experiments, for statistical purposes, each condition was tested 3 times and an average value was reported together with its corresponding standard deviation.

\subsection{Experimental Program}

In this study, three sets of experiments were performed as follows:

First set: using synthetic WW with no heat exchanger.

Second set: using synthetic WW with heat exchanger.

Third set: using real WW with heat exchanger.

The main difference between experiments performed with heat exchanger and those without heat exchanger was the value of the initial temperature $\left(T_{i}\right)$ of the WW when it enters the MW. With no heat exchanger, $T_{i}$ was always $20^{\circ} \mathrm{C}$ (temperature of the source synthetic WW). With heat exchanger, $\mathrm{T}_{\mathrm{i}}$ was in the range of 59 to $71{ }^{\circ} \mathrm{C}$ as shown later in this paper. Energy recovery and cooling the treated effluent are the two main goals of using the heat exchanger.

The effects of initial ammonia concentration, detention time, and initial temperature were investigated. Four detention times $(5,10,15$, and $20 \mathrm{~min})$ and four initial ammonia concentrations $(60,80,100$, and $120 \mathrm{mg} \mathrm{NH} / \mathrm{L})$ were tested in each of the first and second sets of experiments. For each detention time, 4 runs were performed, where each run corresponds to one of the 4 tested ammonia concentrations $(60,80,100 \mathrm{or} 120 \mathrm{mg} / \mathrm{l})$. Thus, the total number of runs performed was 16 in each set of experiments ( 32 runs in the two sets).

In the third set of experiments three concentrations $(55,70$, and $85 \mathrm{mg} \mathrm{NH} / \mathrm{L})$ were tested with the optimum detention time of 10 minutes ( 3 runs). The value of the three ammonia concentrations are based on the characteristics of the real wastewater samples collected from Gaza wastewater treatment plant at different times. The optimum detention time was determined from the results of the first and second sets of experiments as shown later.

In each experimental run, a WW sample was taken every 5 minutes for analysis purposes and the residual ammonia concentration (C) was determined. The system was operated until a steady state residual ammonia concentration $(\mathrm{C})$ was attained.

The detention time of wastewater in the MW reactor was controlled by changing the wastewater pumping flow rate according to following equation:

$$
\theta=\frac{V}{Q}
$$

Where $\theta$ is the detention time in min., $\mathrm{V}$ is the volume of the glass vessel in $\mathrm{ml}$, and $\mathrm{Q}$ is the wastewater flow rate in $\mathrm{ml} / \mathrm{min}$.

The initial $\mathrm{pH}$ for all sets of experiments was set at 11 which was found in our previous work to be the optimum value for removing ammonia nitrogen from municipal wastewater using MW radiation.

\section{Results and Discussion}

\subsection{Performance of the System Using Synthetic WW}

Figure $2(a, b, c, \& d)$ illustrates the performance of the system without using the heat exchanger (first set of experiments-16 runs) while Figure 3 (a, b, c, \& d) illustrates its performance when using the heat exchanger (second set of experiments-16 runs). The two figures show the relation between the residual ammonia concentration $(\mathrm{C})$ and the experiment running time $(\mathrm{t})$. Each experiment lasted for 40 minutes. It was observed that the ammonia residual concentration $(\mathrm{C})$ decreased with time at the beginning of each experiment and reached a steady state value after 20-30 minutes in all the experiments. It was also observed from the two figures that higher ammonia removal was achieved by increasing the detention time $(\theta)$. 


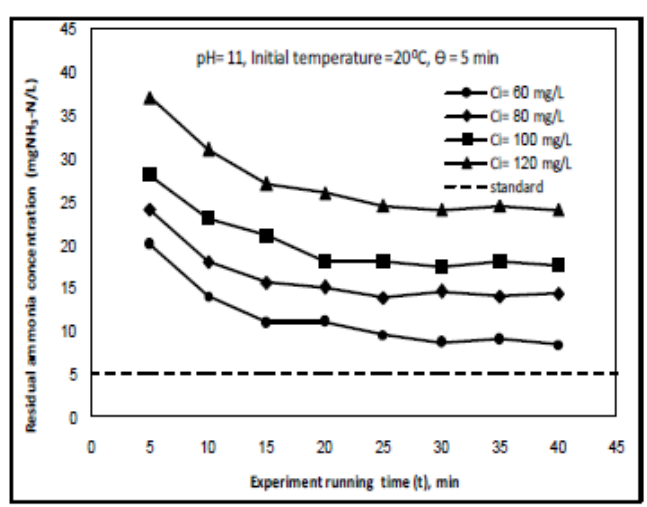

(a) $\theta=5 \min , \mathrm{T}_{\mathrm{i}}=20{ }^{\circ} \mathrm{C}$

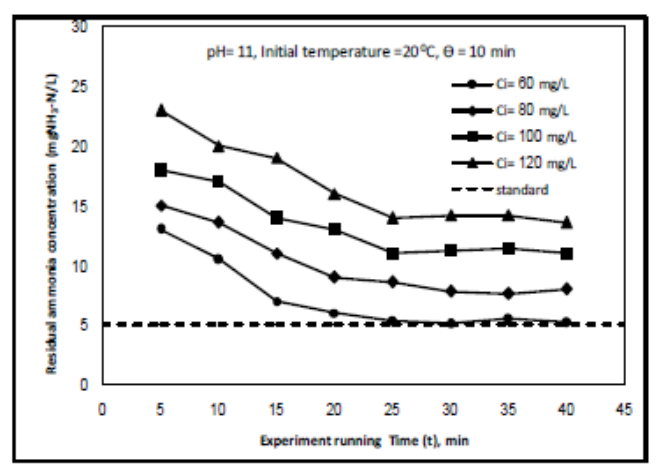

(b) $\theta=10 \mathrm{~min}, \mathrm{Ti}=20^{\circ} \mathrm{C}$

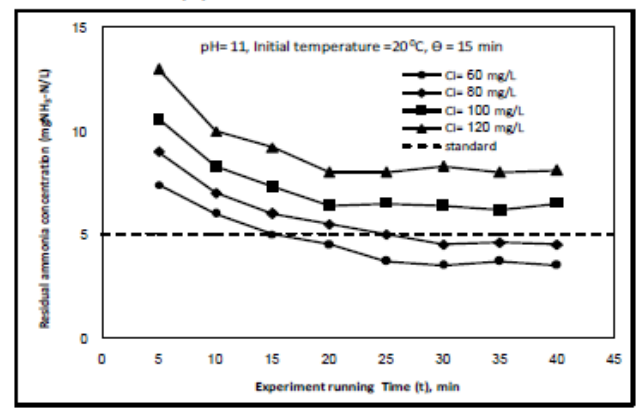

(c) $\theta=15 \min , \mathrm{T}_{\mathrm{i}}=20^{\circ} \mathrm{C}$

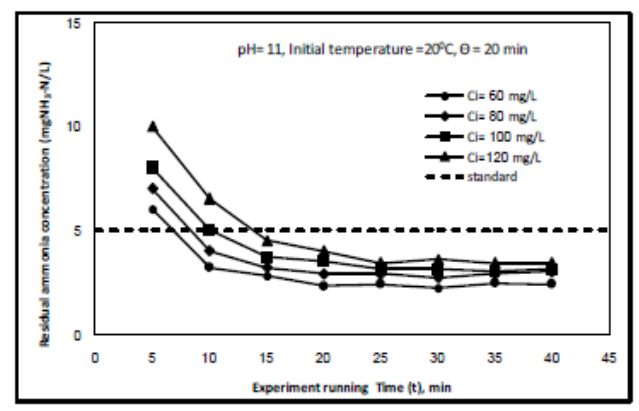

(d) $\theta=20 \min , \mathrm{T}_{\mathrm{i}}=20^{\circ} \mathrm{C}$

Figure 2. Residual ammonia concentration versus time without heat exchanger.

$\left(\mathrm{C}_{\mathrm{i}}=\right.$ initial ammonia concentration $)$

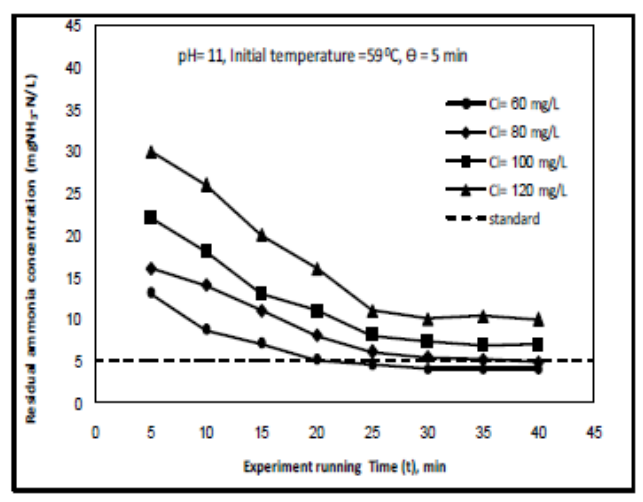

(a) $\theta=5 \min , \mathrm{T}_{\mathrm{i}}=59{ }^{\circ} \mathrm{C}$

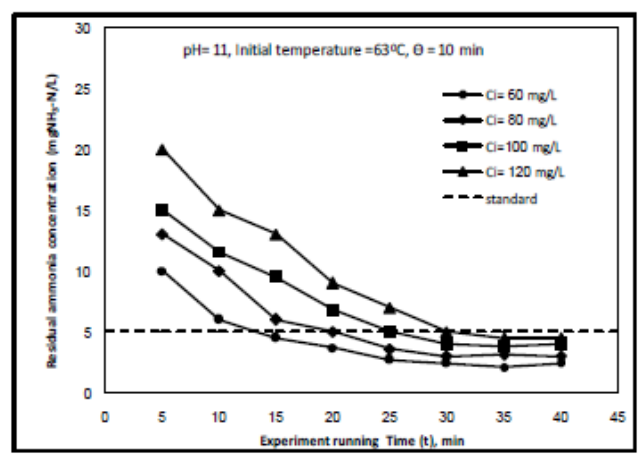

(b) $\theta=10 \mathrm{~min}, \mathrm{Ti}=63^{\circ} \mathrm{C}$

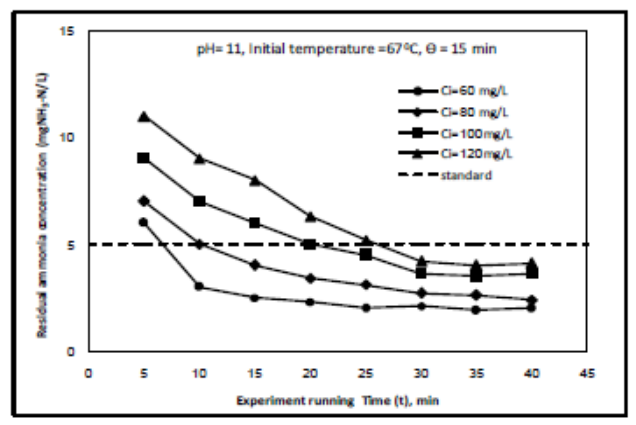

(c) $\theta=15 \min , \mathrm{T}_{\mathrm{i}}=67^{\circ} \mathrm{C}$

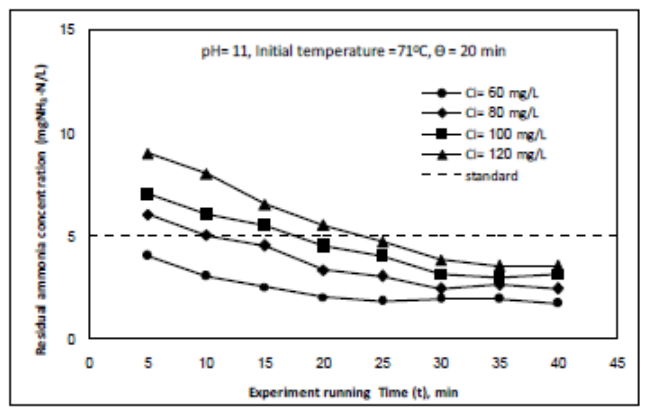

(d) $\theta=20 \mathrm{~min}, \mathrm{~T}_{\mathrm{i}}=71^{\circ} \mathrm{C}$

Figure 3. Residual ammonia concentration versus time with heat exchanger.

$\left(\mathrm{C}_{\mathrm{i}}=\right.$ initial ammonia concentration $)$ 
For example, when $\theta$ was 5 min (Figure 2-a) the residual ammonia steady state concentration (C) was $8.4 \pm 0.3$ $\mathrm{mg} / \mathrm{L}$ while it was $2.4 \pm 0.2 \mathrm{mg} / \mathrm{L}$ (for an initial concentration of $60 \mathrm{mg} / \mathrm{l}$ ) when $\theta$ was $20 \mathrm{~min}$ (Figure 2-d). The same was observed when comparing Figure 3-a and Figure 3-d (for an initial concentration of $60 \mathrm{mg} / \mathrm{l}$ ) as $\mathrm{C}$ was $4.1 \pm 0.4 \mathrm{mg} / \mathrm{l}$ and $2 \pm 0.1 \mathrm{mg} / \mathrm{l}$ for detention times $(\theta)$ of $5 \mathrm{~min}$ and $20 \mathrm{~min}$, respectively. Moreover, $\mathrm{C}$ attained in the experiments with heat exchanger (i.e. results in Figure 3) was lower than that attained in the experiments without heat exchanger (i.e. results in Figure 2). For example, when $\theta$ was 5 min (Figure 2-a) and the initial temperature (Ti) was $20^{\circ} \mathrm{C}$, (C) was $8.4 \pm 0.3 \mathrm{mg} / \mathrm{L}$ (for an initial concentration of $60 \mathrm{mg} / \mathrm{l}$ ) while it was $4.1 \pm$ $0.4 \mathrm{mg} / \mathrm{L}$ when $\theta$ was $5 \mathrm{~min}$ and $\mathrm{T}_{\mathrm{i}}$ was $59^{\circ} \mathrm{C}$ as shown in Figure 3-a indicating better removal efficiency when using heat exchange $(86.7 \%$ versus $93.2 \%$ removals). More elaboration on the effect of detention time and heat exchange effect are given in the following subsections in addition to the effect of the initial ammonia concentration.

\subsubsection{Effect of Detention Time}

To investigate the effect of detention time $(\theta)$, in each run, the initial ammonia concentration $\left(\mathrm{C}_{\mathrm{i}}\right)$ was fixed at a certain value $(60,80,100$ or $120 \mathrm{mg} / \mathrm{l})$ while the detention time was increased in the range of 5 to 20 minutes. Figure 4 illustrates the effect of detention time (i.e. MW radiation time) on the steady state residual ammonia concentration (C) for $C_{i}$ values of $60,80,100$ and $120 \mathrm{mg} / 1$ when the initial temperature $\left(T_{i}\right)$ was kept at $20{ }^{\circ} \mathrm{C}$ via bypassing the heat exchanger. The general observed trend was that $\mathrm{C}$ decreased nonlinearly with the increase of detention time inside the MW reactor for all the ammonia initial concentrations.

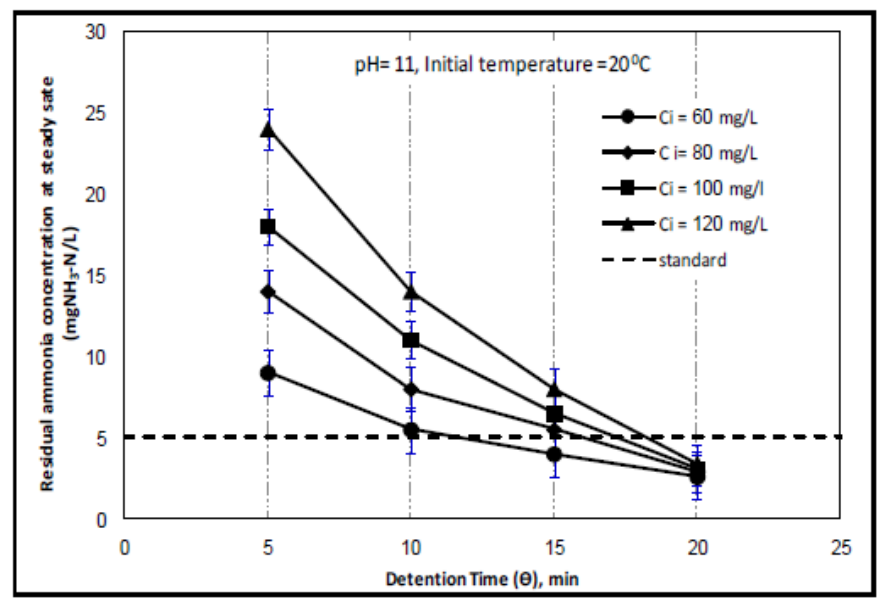

Figure 4. Effect of detention time on ammonia residual steady state concentration without heat exchange $\left(\mathrm{T}_{\mathrm{i}}\right.$ constant at $20^{\circ} \mathrm{C}$ )

For example, for a $\mathrm{C}_{\mathrm{i}}$ value of $80 \mathrm{mg} \mathrm{NH}-\mathrm{N} / \mathrm{L}$, the steady state residual ammonia concentrations were $14,8,6$ and 3.5 for detention times of 5, 10, 15, and $20 \mathrm{~min}$, respectively. The same trend was observed for the remaining concentrations as interpreted from Figure 4. The improved performance with the increase of detention time is attributed to the increased heating energy induced by the MW radiation that increased in turn the water molecules random motion leading to the increase of ammonia mass transfer out of the liquid phase. To make sense of the removal efficiency, the ammonia residual (C) is compared to the ammonia standard for wastewater reuse for recharge to the groundwater which is $5 \mathrm{mg} \mathrm{NH}_{3}-\mathrm{N} / \mathrm{L}$ (JISM, 2006). The standard concentration was achieved at 11, 16, 18 and 19 min for $\mathrm{C}_{\mathrm{i}}$ values of 60, 80, 100 and $120 \mathrm{mg} \mathrm{NH}_{3}-\mathrm{N} / 1$, respectively (Figure 4).

\subsubsection{Effect of Initial Temperature}

The initial temperature $\left(\mathrm{T}_{\mathrm{i}}\right)$ was constant at $20^{\circ} \mathrm{C}$ in the first set of experiments when the heat exchanger was bypassed. However, in the second set of experiments, when the heat exchanger was employed, $T_{i}$ increased with the increase of detention time $(\theta)$. $T_{i}$ was $59,63,68$, and 71 when the detention time was $5,10,15$, and 20 min, respectively. Figure 5 illustrates the effect of initial temperature on the steady state residual ammonia concentration (C) for $\mathrm{T}_{\mathrm{i}}$ range of 59 to $71{ }^{\circ} \mathrm{C}$. The removal efficiency when $\mathrm{T}_{\mathrm{i}}$ was $20^{\circ} \mathrm{C}$ can be observed from Figure 4. Since $T_{i}$ and $\theta$ are dependent variables when using the heat exchanger, it was necessary to isolate the effect of $\theta$ while studying the effect of $\mathrm{T}_{\mathrm{i}}$. This was achieved by comparing the value of $\mathrm{C}$ at $\mathrm{T}_{\mathrm{i}}$ of $20^{\circ} \mathrm{C}$ at a 
specified detention time $(5,10,15$, or 20 minutes $)$ with $\mathrm{C}$ at the corresponding $\mathrm{T}_{\mathrm{i}}\left(59,63,68\right.$, or $\left.71{ }^{\circ} \mathrm{C}\right)$. For Example, by reading Figures 4 and 5 , when $\theta$ was 5 minutes, $\mathrm{T}_{\mathrm{i}}$ was either 20 or $59{ }^{\circ} \mathrm{C}$ and when $\theta$ was 20 minutes, Ti was either 20 or $71^{\circ} \mathrm{C}$. It was observed that the removal of ammonia increased by the increase of initial temperature. For example, for $\mathrm{C}_{\mathrm{i}}=100 \mathrm{mg} / \mathrm{L}$ and $\theta=10$ minutes, $\mathrm{C}$ was $11.2 \pm 0.5 \mathrm{mg} / \mathrm{L}$ (from Figure 4) and $3.8 \pm 0.3 \mathrm{mg} / \mathrm{L}$ (From Figure 5) when $\mathrm{T}_{\mathrm{i}}$ was 20 and $63{ }^{\circ} \mathrm{C}$, respectively. An important result was also concluded regarding the achievement of a specified standard residual value such as $5 \mathrm{mg} \mathrm{NH}_{3}-\mathrm{N} / 1$ for the purpose of recharge (Jordanian standards, 2006). The results indicate that a specified standard can be achieved by lower detention time when using higher $T_{i}$ values by means of heat exchanger. For example, for $C_{i}=100 \mathrm{mg}$ $\mathrm{NH}_{3}-\mathrm{N} / \mathrm{L}$, the standard concentration required 15 minutes detention time to be achieved, while it was achieved at a detention time of 8.5 minutes only when the heat exchanger was used. This finding is very important in terms of the economical feasibility of such a system. Lower detention times mean lower reactor volume and lower power consumption per treated cubic meter of WW.

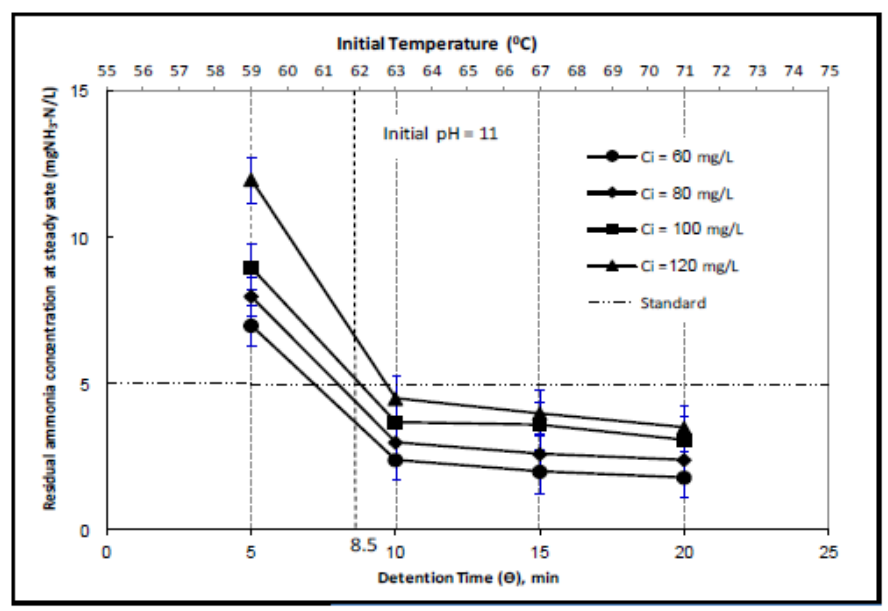

Figure 5. Effect of initial temperature on ammonia residual steady state concentration (with heat exchanger)

\subsubsection{Effect of Initial Ammonia Concentration}

Four initial ammonia concentrations $\left(\mathrm{C}_{\mathrm{i}}\right)$ were tested in this work, namely: 60, 80, 100 and $120 \mathrm{mg} \mathrm{NH}_{3}-\mathrm{N} / 1$. These concentrations are in the typical range of ammonia concentrations in real municipal wastewater (CMWU, 2010). To investigate the effect of $C_{i}$, the detention time $(\theta)$ was fixed at a certain value $(5,10,15$ or $20 \mathrm{~min})$ while $C_{i}$ was changed to one of the above mentioned 4 concentrations. Figure 6 illustrates the effect initial ammonia concentrations $\left(\mathrm{C}_{\mathrm{i}}\right)$ on the steady state residual ammonia concentration $(\mathrm{C})$ when the initial temperature $\left(\mathrm{T}_{\mathrm{i}}\right)$ and $\mathrm{pH}$ were kept constant at $20^{\circ} \mathrm{C}$ and 11 , respectively.

It is observed from Figure 6 that at low detention time $(\theta)$ the increase of initial ammonia concentration $\left(C_{i}\right)$ resulted in higher ammonia steady state residual concentration (C) (i.e. lower removal efficiency). For example, when $\theta$ was 5 minutes, $\mathrm{C}$ increased from 26 to $38 \mathrm{mg} \mathrm{NH}-\mathrm{N} / \mathrm{L}$ when $\mathrm{C}_{\mathrm{i}}$ increased from 60 to $120 \mathrm{mg} / \mathrm{L}$. On the other hand, it was observed that at high $\theta$ the effect of $\mathrm{C}_{\mathrm{i}}$ on $\mathrm{C}$ decreases and becomes negligible. For Example, when $\theta$ was 15 minutes, $C$ increased from 6 to $11 \mathrm{mgNH}_{3}-\mathrm{N} / \mathrm{L}$ only when $\mathrm{C}_{\mathrm{i}}$ increased from 60 to $120 \mathrm{mg}$ $\mathrm{NH}_{3}-\mathrm{N} / \mathrm{L}$. Moreover, when $\theta$ was 20 minutes, $\mathrm{C}$ was almost constant when $\mathrm{C}_{\mathrm{i}}$ increased from 60 to $120 \mathrm{mg}$ $\mathrm{NH}_{3}-\mathrm{N} / \mathrm{L}$ (i.e. $\mathrm{C}$ increased from 3 to $3.5 \mathrm{mg} / \mathrm{L}$ only).

This phenomenon can be attributed to the variations of ammonia mass transfer rate due to the change of the heating energy induced into the wastewater by microwave radiation. At low detention time the heating energy in the wastewater is low and has a corresponding low constant ammonia mass transfer rate. So when $\mathrm{C}_{\mathrm{i}}$ increases $\mathrm{C}$ also increases. On the other hand, at high detention time the heating energy in the wastewater is high and has a corresponding high constant ammonia mass transfer rate that is enough to overcome he increase in $C_{i}$ and consequently results in constant value of $\mathrm{C}$ for all values of $\mathrm{C}_{\mathrm{i}}$. 


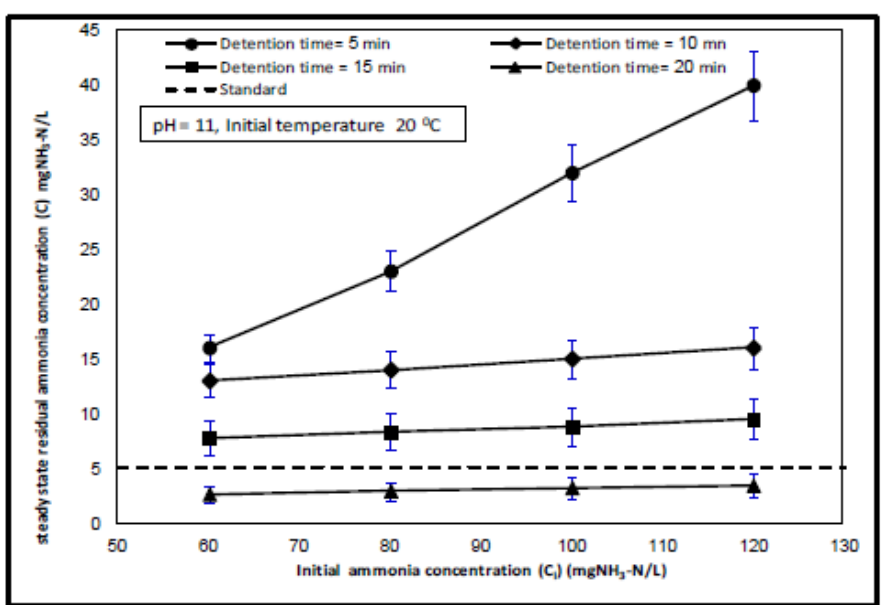

Figure 6. Effect of initial ammonia concentration on ammonia residual steady state concentration (without heat exchanger)

\subsection{Performance of the System Using Real WW With Heat Exchanger}

The third set of experiments was performed to study the performance of the system when treating real wastewater. The experiments were performed using three wastewater samples that were collected from Gaza wastewater treatment plant effluent. Samples characteristics and the sampling dates are given in Table 1.

Table 1. Characteristics of the real wastewater samples

\begin{tabular}{ccccccc}
\hline Sample \# & Collection date & $\mathrm{pH}$ & $\mathrm{BOD}_{5}\left(\mathrm{mg} \mathrm{O}_{2} / \mathrm{L}\right)$ & $\mathrm{TSS}(\mathrm{mg} / \mathrm{L})$ & $\mathrm{NH}_{3}\left(\mathrm{mg} \mathrm{NH}_{3}-\mathrm{N} / \mathrm{L}\right)$ & $\begin{array}{c}\text { Fecal Coliform } \\
(\mathrm{Cell} / 100 \mathrm{ml})\end{array}$ \\
\hline 1 & $03 / 01 / 2012$ & 7.3 & 115 & 75 & 65.7 & 3190 \\
2 & $03 / 13 / 2012$ & 7.1 & 135 & 126 & 94.6 & 4370 \\
3 & $04 / 03 / 2012$ & 7.5 & 90 & 92 & 73.8 & 2460 \\
\hline
\end{tabular}

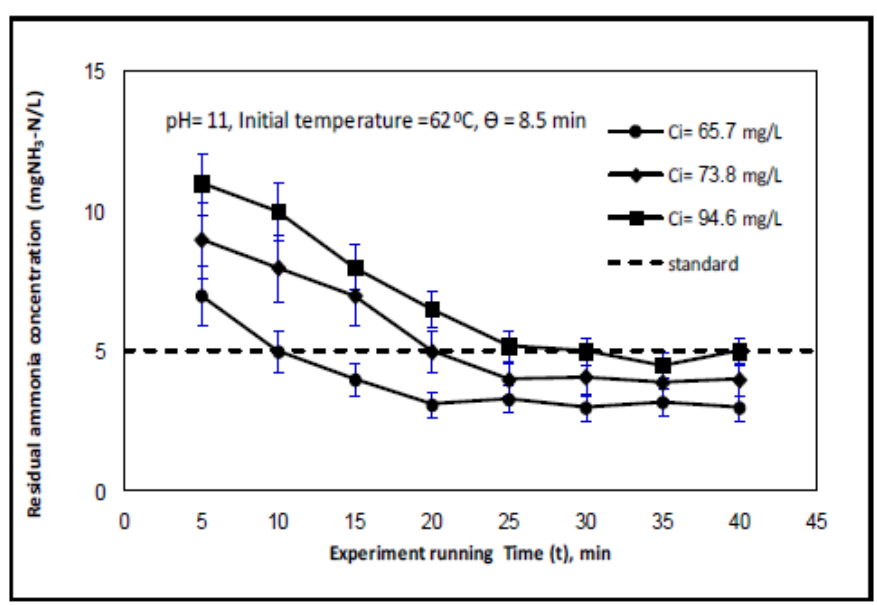

Figure 7. Performance of the continuous microwave system in removing ammonia from real domestic wastewater

The third set of experiments was run using the optimum conditions determined from the first and second sets of experiments that were performed on synthetic wastewater as indicated above. The detention time used was 8.5 


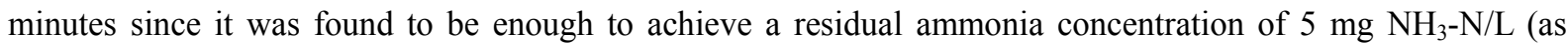
indicated in item 3.1.2). The initial temperature $\left(\mathrm{T}_{\mathrm{i}}\right)$ was $62{ }^{\circ} \mathrm{C}$ as a result of using the heat exchanger. The $\mathrm{pH}$ was set at the optimum value of 11 . Three runs were performed where each run corresponds to one of the three initial ammonia concentrations presented in Table 1 (i.e. 65.7, 73.8, $94.6 \mathrm{mg} \mathrm{NH}_{3}-\mathrm{N} / \mathrm{L}$ ). Figure 7 shows the performance of the system in removing ammonia from real domestic wastewater under the described conditions. It was observed that the ammonia residual concentration (C) decreased with time at the beginning of the process then it reached a steady state value after 20-30 minutes for the three runs. The residual steady state ammonia concentration (C) was found to be $3.1 \pm 0.2,4.0 \pm 0.1$ and $4.9 \pm 0.3 \mathrm{mg} \mathrm{NH}-\mathrm{N} / \mathrm{L}$, for the initial concentrations 65.7, 73.8, and $94.6 \mathrm{mg} \mathrm{NH}_{3}-\mathrm{N} / \mathrm{L}$, respectively. This indicates that the ammonia standard concentration of $5 \mathrm{mg}$ $\mathrm{NH}_{3}-\mathrm{N} / \mathrm{L}$ can be achieved under conditions described in this study. It was also observed that the ammonia removal efficiency and the residual ammonia concentrations are similar to that of the synthetic wastewater. This indicates that other constituents in the municipal wastewater such as organic matter and suspended solids have no significant effect on the ammonia removal by MW radiation.

\section{Conclusion}

This research was carried out to explore ammonia nitrogen removal from municipal wastewater using a continuous microwave system equipped with heat exchanger. The effects of ammonia initial concentration, radiation time, and wastewater initial temperature were investigated. It was concluded from the experiments performed on synthetic wastewater that the optimum conditions for this system are using a detention time of 8.5 minutes that leads to an initial temperature of $62{ }^{\circ} \mathrm{C}$ when using the heat exchanger. These conditions are valid for the range of initial concentrations between 60 and $120 \mathrm{mg} \mathrm{NH}_{3}-\mathrm{N} / \mathrm{L}$ a concentration range typical for municipal wastewater. The residual ammonia concentrations under these conditions were $3.5 \pm 0.4,4.4 \pm 0.4,5.1$ \pm 0.2 , and $6.9 \pm 0.5 \mathrm{mg} \mathrm{NH}_{3}-\mathrm{N} / \mathrm{L}$ for initial concentrations of $60,70,80,100$, and $120 \mathrm{mg} \mathrm{NH}_{3}-\mathrm{N} / \mathrm{L}$, respectively. Similar ammonia removals were achieved with real municipal wastewater samples that were treated under the same conditions. The residual steady state ammonia concentration (C) was found to be $3.1 \pm 0.2,4.0 \pm 0.1$ and $4.9 \pm 0.3 \mathrm{mg} \mathrm{NH}-\mathrm{N} / \mathrm{L}$, for the initial concentrations 65.7 , 73.8, and $94.6 \mathrm{mg} \mathrm{NH}-\mathrm{N} / \mathrm{L}$, respectively. It is concluded from these results that the optimum conditions for ammonia removal from real wastewater by MW radiation are: detention time of 8.5 minutes, $\mathrm{pH}$ of 11, and using heat exchanger (to achieve initial temperature of $62{ }^{\circ} \mathrm{C}$ or better). These conditions apply for initial ammonia concentrations in the range of 65 to $95 \mathrm{mg} \mathrm{NH}-\mathrm{N} / \mathrm{L}$ which is the typical range of concentrations in municipal wastewater. This study suggests that MW radiation operated in a continuous mode is a promising technology for removal of ammonia nitrogen from municipal wastewater.

\section{Acknowledgement}

The authors would like to acknowledge and appreciate the complete financial support of this research by The Middle East Desalination Research Center (MEDRC).

\section{References}

APHA, AWWA and WEF. (1989). Standard Methods for the Examination of Water and Wastewater (17th ed.). Washington, DC: APHA.

Bermejo, M. D., Centero, F., \& Cocero, M. J. (2008). Supercritical water oxidation of feeds with high ammonia concentrations: Pilot plant experimental results and modeling. Chemical Engineering Journal, 137(3), 542-549. http://dx.doi.org/10.1016/j.cej.2007.05.010

Bochenek, R., Sitarz, R., \& Antos, D. (2011). HYPERLINK Design of continuousion exchange process for the $\begin{array}{lllll}\text { wastewater treatment. Chemical Engineering } & \text { Science, 66(23), }\end{array}$ http://dx.doi.org/10.1016/j.ces.2011.08.046

Boldor, D., Balasubramanian, S., Purohit, S., \& Rusch, K. A. (2008). Design and Implementation of a Continuous Microwave Heating System for Ballast Water Treatment. Environmental Science and Technology, 42(11), 4121-4127. http://dx.doi.org/10.1021/es7024752

Chien, Y. (2012). Field study of in situ remediation of petroleum hydrocarbon contaminated soil on site using microwave energy. Journal of Hazardous Materials, 199-200, 457-461. http://dx.doi.org/10.1016/j.jhazmat.2011.11.012

Coastal Municipalities Water Utility. (2010). Wastewater lab tests results, Gaza, Palestine.

Değermenci, N., Ata, O. N., \& Yildiz, E. (2012). Ammonia removal by air stripping in a semi-batch jet loop reactor. Journal of Industrial and Engineering Chemistry, 18(1), 399-404. 
http://dx.doi.org/10.1016/j.jiec.2011.11.098

Demirer, S. U., Demirer, G. N., \& Chen, S. (2005). Ammonia removal from anaerobically digested dairy manure by struvite precipitation. Process Biochemistry, 40(12), 3667-3674. http://dx.doi.org/10.1016/j.procbio.2005.02.028

Gujer, W. (2010). Nitrification and me-A subjective review. Water Research, 44(1), 1-19. http://dx.doi.org/10.1016/j.watres.2009.08.038

JISM. (2006). Water-Reclaimed domestic wastewater. Technical Regulation, Jordanian Institution for Standards and Metrology, Jordan.

Jou, C. G. (2006). An efficient technology to treat heavy metal-lead-contaminated soil by microwave radiation. Journal of Environmental Management, 78(1), 1-4. http://dx.doi.org/10.1016/j.jenvman.2004.11.020

Lin, L., Chen, J., Xu, Z., Yuan, S., Cao, M., Liu, H., \& Lu, X. (2009). Removal of ammonia nitrogen in wastewater by microwave radiation: A pilot-scale study. Journal of Hazardous Materials, 168(2-3), 862-867. http://dx.doi.org/10.1016/j.jhazmat.2009.02.113

Rabah, F. K., \& Darwish, M. S. (2013). Characterization of Ammonia Removal from Municipal Wastewater Using Microwave Energy: Batch Experiment. Environment and Natural Resources Research, 3(1), 42-50. http://dx.doi.org/10.5539/enrr.v3n1p42

Robinson, J. P., Kingman, S. W., Lester, E. H., \& Yi, C. (2012). Microwave remediation of hydrocarbon-contaminated soils-Scale-up using batch reactors. Separation and Purification Technology, 96(21), 12-19. http://dx.doi.org/10.1016/j.seppur.2012.05.020

Sun, Y., Zhang, Y., \& Quan, X. (2008). Treatment of petroleum refinery wastewater by microwave-assisted catalytic wet air oxidation under low temperature and low pressure. Seperation and Purification Technology, 62(3), 565-570. http://dx.doi.org/10.1016/j.seppur.2008.02.027

Xiao, Y. B., Wang, P., Jiang, H., Xu, H., Shi, S., \& Huang, J. (2007). Treatment of phenol wastewater by microwave-induced $\mathrm{ClO}_{2}-\mathrm{CuOx} / \mathrm{Al}_{2} \mathrm{O}_{3}$ catalytic oxidation process. Journal of Environmental Sciences, 19(12), 1510-1515.

Yang, M., Uesugi, K., \& Myoga, H. (1999). Ammonia removal in bubble column by ozonation in the presence of bromide. Water Research, 33(8), 1911-1917. http://dx.doi.org/10.1016/S0043-1354(98)00364-9

Yang, Y., Wang, P., Shi, S., \& Liu, Y. (2009). Microwave enhanced Fenton-like process for the treatment of high concentration pharmaceutical wastewater. Journal of Hazardous Materials, 168(1), 238-245. http://dx.doi.org/10.1016/j.jhazmat.2009.02.038 